\title{
The Role of Theatrical Art in the Preservation of Historical Memory in the Example of Volga Region at the Beginning of the Century
}

\author{
Ludmila N. Brodovskaya $^{1} \&$ Vera V. Buravleva ${ }^{1}$ \\ ${ }^{1}$ Kazan (Volga Region) Federal University, Kazan, Russia \\ Correspondence: Ludmila N. Brodovskaya, Kazan (Volga Region) Federal University, 420008, Kazan, \\ Kremlyovskaya Street 18, Russia. E-mail: ludmilabrod@mail.ru
}

Received: June 2, 2015 Accepted: June 15, 2015 Online Published: June 29, 2015

doi:10.5539/jsd.v8n5p99 URL: http://dx.doi.org/10.5539/jsd.v8n5p99

\begin{abstract}
The importance of the problem under investigation is determined by the role of theatrical art in shaping the social and political position of the Volga region's population at the beginning of the twentieth century. The possibility of usage of the cultural and historical experience for the development of state policy in the sphere of preservation and development of historical memory, since in the period of major socio-cultural changes not only redefining the country's history happens, but also deliberately "forgetting" some of its stages. The article aims to disclose the place and role of the Russian Social-Democracy in the social life of Russia at the beginning of the twentieth century in the examples of the Volga region creative intelligentsia participation, namely actors in the events of the revolution of 1905-1907. The research objectives and characteristics of the material under study determined the choice of comparative-historical method and specific analysis as the main research methods, most fully disclosing methodological principle of historicism. The article highlights the main factors influencing the formation of historical memory (historical education, the arts, public policy), and shows the role of creative intelligentsia in the formation of the historical memory of the Volga region population in the early XX century. The article Submissions can be used in the process of teaching, generalizing works on the history and culture of Russia, in the educational work with the students, in decision-making in the social and cultural sphere.
\end{abstract}

Keywords: historical memory, historical education, performing arts, Volga Region, at the beginning of the XX century

\section{Introduction}

In the twentieth century, the problem of historical memory popped to the forefront and at the same time, there appeared new approaches directed to the study of the images of the past in the public consciousness. In post-Soviet Russia a new historical memory on the basis of a new mythology started to be created. Nowadays the study of the past, based on documentary materials, should help to restore the missing links in our history. It is important to bear in mind that Russia - is the center of Eurasia; it is a meeting point of East and West. This characteristic directly related to the Volga region, where for a long period conditions for the dialogue of cultures were created.At the end of the XIX- beginning of the XX century L. Brodovskaya (2012), V. Buravleva (2012) and A. Gafarov researched in their articles the problems of "inorodcheskiy" education of Muslims in the Russian Empire (2012). The authors came to conclusion of the colonial nature of the educational policy, although the system of "inorodcheskiy" education became an important factor in the education of the Muslims. B. Buravleva (2012) and A. Gafarov (2012) noted the extremely uneven distribution of European innovations in the Muslim world, the impact of these processes on the Russian acculturation and Westernization in the Middle East.Russian culture became an active promoter introducing the achievements of European civilization to the Russian Muslims.

L. Brodovskaya investigated the study of the theatrical art's specific place in the spiritual life of Russian society at the beginning of the twentieth century $(2008 ; 2009 ; 2012 ; 2013)$. They show that the degree of communicative skills of various arts does not remain unchanged; on the contrary, it is closely linked to a number of circumstances and conditions both the current and deep, cultural and historical ones. Before the approval of the cinema as the main method of ideological and aesthetic influence on society, the theatrical art had a prominent role in the cultural and political interrelations. Besides, on the bases of the content analysis of 
the Volga print, the author proves that in the environment of social changes experienced by the Russian society at the beginning of the twentieth century, the stage images transformed into effective means of influence on the public opinion of the educated people. The expectations and the political leanings of the people largely determined the result of social changes. Theatre determined its social position through the repertoire. In the years of revolution and social upheaval aimed at denying the existing reality, theatre staged those plays, dramaturgy of which were "working" on the idea of a radical transformation of the social structure. It was not a coincidence that during the revolution public political speeches were made in the theatres. The drama of Gorky took a special place in the repertoire of the theatres (Brodovskaya 2013). During this period, folk theatres turned under the influence of the Social Democrats, and formation of the national theatres started. The revolution of 1905-1907 stirred progressive Tatar intellectuals who were actively involved in the revolutionary liberation movement that spread throughout the country. The revolution brought the opportunity to publish newspapers and magazines in their native languages, which marked a new stage in the development of national culture. New inducements for the development of the theatrical arts were received. G. Kamal, F. Amirhan, R. Ramiev G. Kulahmetov actively participated in the creation of the Tatar Theatre and the formation of a democratic repertoire (Brodovskaya 2013). Thus reconstructing the cultural life of Russia in the critical period of its development, we can see that a significant part of the multinational artistic and creative Volga region intelligentsia showed the desire to be engaged in a nationwide assault on tsarism because of the "Asian" methods of government policy in the spiritual realm. This material suggests that there were not two, but three areas - conservative, liberal and socialist ones in the Russian social movement.

The analysis of the works in terms of investigated problems showed that the issues related to the theatrical art role in the formation of the historical memory on the example of the Volga region remain unexplored scientific knowledge. This finding made us formulate the hypothesis of the problem study: the main factors influencing the formation of historical memory are public policy, historical education, art (including theatre).

\section{Materials and Methods}

\subsection{The Objectives of the Research}

In the study, the following tasks were investigated: 1) determination of the category "historical memory"; 2) the allocation of the main factors influencing the formation of historical memory (historical education, the arts, public policy); 3) collection of the materials on the activities of the creative intelligentsia of the Volga region at the beginning of the XX century; 4) the analysis of the data collected in order to recreate their practices based on the overall picture of the interaction of public policy, historical education, and the Volga region theatre at the beginning of the XX century in the formation of the historical memory of the region's population.

\subsection{Theoretical and Empirical Methods}

To test the hypothesis we used general scientific methods of theoretical analysis synthesis, analogy, and a special empirical comparative historical method, which most fully reveals the methodological principle of historicism.

\subsection{The Basis of the Research}

The basis of the study was the work of the Volga region creative intelligentsia at at the deginning of the XX century.

\subsection{Proceedings and Description of the Experiment}

In the initial phase of the survey, we analyzed the theoretical and methodological works on the problem of historical memory and we distinguished the following main factors influencing the formation of historical memory: public policy, historical education, art.

The next step was to collect material about the activities of the Volga region scientific and creative intelligentsia at the beginning of the XX century.

A conducted further analysis shows that the arts indeed (including theatrical), along with government policies and historical education plays an important role in shaping historical memory.

\section{Results}

\subsection{Formation of Historical Memory in Post-Soviet Russia}

The creation of a new historical memory in post-Soviet Russia passed several stages. First, "pendulum" of historical researches swung towards "clean", "ideal" liberalism, then in the direction of the same "ideal" 
conservatism. A new mythology started to be created, it was very often when "+" changed into "-" in the evaluation of a personality (remember, the evaluation of historical figures like Lenin, Stolypin, Kolchak, Denikin) or historical events (f.e., Civil War). It is reflected not only in the historical books, but also in literature and art. It contributed to the formation of social consciousness, based on the ideological interests of the political elite. As a result, the third direction of social and political thought - socialistic one disappeared or almost disappeared from the historical memory. It became more difficult to understand, especially for the younger generation, why at the end of XIX- early XX centuries the socialist ideas attracted the students, scientific and creative intelligentsia, and why the Russian intelligentsia of at the beginning of the XX century was characterized by the phenomenon of the ever-growing sympathy for the proletariat and socialism.

One of the main problems to be solved by the historical science is the formation of the image (or images) of the past. That past is reflected in the textbooks written based on historical science.

A teacher using textbooks in the course of history implements several functions: informative, educational and identifying. The Russian and Soviet historians solved the problem of identity in different periods in different ways. There was time when the Russian history was written as a collective biography of the ruling dynasty, there was a period when the history of the Russian people - and the nation became the main one, and it was a period when the country's history was associated only with the labor people, the demos.

And this is not surprising, since, according to N.A. Berdyaev (1980), "memory (including books, they are imprinted memory) is not just a passive reproduction of the past ... but it is a kind of "spiritual activity" elective and creative directed not only to the understanding of the past, but to its transformation as well."

The course of history is to help the students to understand why at the beginning of the XX century the Russian intelligentsia and the students were so passionate about "socialism" and "revolution." It can be done on the example of the participation of the creative intelligentsia of the Volga region, namely actors, in the events of the revolution 1905-1907 yy. Besides, the participants of the revolution of that kind were not described in our textbooks.

\subsection{The Place and Role of the Theatre in the Russian Society at the Beginning of the XX Century}

At the beginning of XX century, the traditional views on the theatre changed in Russia, stage images transformed into effective means of influencing the public position of the educated people. Russian press at the beginning of the XX century noticed that for Russia "plays and theatres ... are the same things as for a Western European, parliamentary events and political speeches." Clash of the society and the authorities during the first Russian revolution of 1905-1907 could not but affect the theatrical environment, sensitive to the moods of the audience. In the work of the Imperial Theatres, pro-government orientation was clearly traced. Private theatres usually held the position at the opposite pole, expressing the spirits of the progressive people. K.S. Stanislavsky expressed the mood of the creative intelligentsia: "At the moment of social forces awakening in the country, the theatre cannot and is not allowed to serve only pure art - it has to respond to public spirits, to explain them to the public, theatre is to be a teacher of the society" (Stanislavski, 1953).

The ruling elite tried to reduce radicalizing effect of the theatres captured by "poetics" of the revolution, on the population, using censorship and available methods of administrative influence. However, the unwillingness of the government to be engaged in dialogue with the public, did not contribute to the development of a clear strategy for responding to the "opposition" spirits "La Boheme". The distance from the capital increased the confusion of the powers, manifested, particularly, in strengthening the enforcement measures in regard to the actors. For example, the play allowed to be staged for the imperial theatres, often could not be played on the provincial stage.

Kazan theatre was a private theatre and N.I. Sobolschikov-Samarin was the head of it. He was an educated person and understood the place of theatre in social life very well. On the one hand due to him, the theatre became a platform of social life, and on the other - the actors refused to participate in the Black Hundreds performances that pointed to their democratic orientation.

In connection with the staging of the Black Hundred performances on the one hand, and the refusal of a number of actors to participate in them, on the other hand, the press of that time raised the question about an actor-citizen. The question that extended the life itself, "whether the actors by their talent are obliged to maintain the performance, which they honestly admit as socially impolite and socially harmful?" Journal "Theatre and Art" summed up and wrote that "to force the actors to be involved in such plays - means, "to humiliate grossly actors and stage, to deny their noble and essential public mission "(Brodovskaya, 2012).

The correspondence of Saratov and Kazan actors of choir and orchestra proved the fact that the refusal to 
participate in the play meant a serious act of civil values for an actor. The Kazan actors asked their colleagues from Saratov to support their strike and not to accept the invitation of the Kazan entrepreneur Mandelstam. The reason of it was that after the announcement of the strike the entrepreneur Mandelstam "came to the police station and said that the musicians like the Jews, can stay in Kazan only if they play in the theatre orchestra, and as soon as they cease to play, they must be expelled from Kazan to their places of registration".

A peculiar demonstration of the political position of the Kazan Theatre was the E. Chirikov's play "The Jews" during its presentation they made political speeches and sang revolutionary songs. The Government noted that political demonstration ("Jews" were also staged in Saratov, Samara and Nizhny Novgorod) and banned the staging of "the Jews" in those cities where by the ruling bureaucracy logics, could cause national strife "(Brodovskaya 2012).

In addition, in protest against the anti-Jewish massacre, in October 1905 the theatre suspended performances for seven days, and they opened by the Gorky's play "Dety solntsa". The theatre was an unprecedented spectacle. The police was absent. All previously existing police posts both around and inside the theatre, were held up by the militia, which consisted of the students. The students also occupied the auditorium seats reserved for the bailiff and the police chief. During the intermissions, the youth sang revolutionary songs, made speeches, collected donations to help the victims "(Brodovskaya, 2008).

The newspapers of other cities also noted success of the Gorky play. During the presentations there were political demonstrations, for example, in Samara during the presentation of "Deti solntsa" they made revolutionary speeches. The police tried to detain them, and only the interference of the public prevented making arrests (Altshuller, 1956). "Samarskiy kuryer" noted that "the theatre got a new custom: during the intermissions the audience sings revolutionary songs" (Brodovskaya, 2008).

The Volga region theatre staged all the plays of Gorky (during the revolution, they had a special place in the repertoire). Their presentation turned into a political demonstration: during the performances, they scattered leaflets, proclamations there was "fraternization" with the actors, and in the intervals, they made revolutionary speeches, and sang "La Marseillaise."

The students profile survey in the diploma of a law student N. Astrov, given in 1907, confirms the popularity of Gorky at the beginning of the century. In the first place among writers the students put L. Andreev and M. Gorky, then A. Chekhov, L. Tolstoy and V. Korolenko, among philosophers - K. Marx, and among publicists G. Plekhanov (Smykov and Shishkin, 2002) .

The political position of the theatre also manifested in the staging charity performances and parties, the fees from which were sent to the strikers, the arrested and the exiled.

The police authorities attentively watched this side of the provincial artistic intelligentsia activities. In particular, one of the reports informed that on November 30, 1905 in Nizhny Novgorod City Theatre the actors' partnership gave a performance, its fee went in favor of the local Social-Democratic Labour Party. November 25 Nizhny Novgorod Theatre performed the play by Schiller's "Don Carlos" in favor of the amnestied. "Samara newspaper" reported that "on December 21 City Theatre gives a performance the fee of which goes in favor of the Samara circle for spreading political awareness" (Brodovskaya, 2008).

\subsection{Involvement of Amateur Folk Theatres under the Influence of the Social Democrats}

The idea of creating a "national theatre" at the turn of XIX-XX centuries was popular between liberal and the revolutionary intelligentsia. It had its supporters in the government as well. Gorky, Chaliapin, Stanislavsky took part in the creation of national theatres. Gorky and Chaliapin provided financial assistance to the national theatres (Brodovskaya, 2009), and Stanislavsky, starting with the 90-ies of XX century, repeatedly appealed to the State Duma with the project of national theatres. He proposed to create two theatrical societies: "National Public Theatre" and mobile "provincial theatres" that were supposed to go to the provinces and perform new plays in the factories. K.S. Stanislavsky linked his project to the social upheaval in the country, with a "moment of cultural development", which was experienced by Russian society, when art "came out and stepped into the crowd, living full of all the variety around "(Rogachevskiy, 1956).

On the contrary, the tsarist government accepted the organization of "folk theatres" as one of the methods of struggle against the revolutionary movement.

"Folk" theatres ran by guardianship of national sobriety, and special censorship operated the repertoire of the theatres, it prevented the theatres from staging of such plays as "Na dnye" and "Meshane" by Gorky, "Dyadya Vanya" by Chekhov, Shakespeare's tragedies "Hamlet," "Othello," "King Lear" and others. 
At the end of 1905, the government, frightened by the increase of the revolutionary wave, intensified oppression of censorship, banned staging the plays, which featured the "crowd." All so-called conditional permits for individual theatres were abolished, and as a result, many folk theatres lost their best repertoire.

However, a further rise of the revolutionary movement in the country forced the tsarist government to ease temporarily the oppression of censorship. The "national" theatres were allowed to stage all the plays permitted by the total censorship, particularly, "Na dnye" by Gorky, "Deti Vanyushina" by Naidenov, "Intrigue and Love" by Schiller, "Gorkaya sudbina" by Pisemsky. Still "Vishneviy sad" by Chekhov was banned because "the degeneration of the nobility was depicted in bright colors" and "Deti solntsa" by Gorky. The last one - "in view of the fact that the performance of the play in St. Petersburg and Moscow, made great impression on the audience, led to the theatre scandals. It was unacceptable to happen scandals in the county-level cities, and especially in the villages, where plays for the people were staged. "

Democratic intelligentsia welcomed the staging "The Jews" by Chirikov at the National Theatre and recently banned "Deti Vanyushina". Those presentations were accompanied by the singing the "Marseillaise" and "applauses and shouts of "bravo", which the audience greeted the actors ... were the signs of compassion." Presentation of "The Jews" at the National Theatre was of great importance "in the sense of mass upbringing, causing an aversion to massacres and outrages sympathy for the suffering people" (Brodovskaya 2013). It should be noted that part of the humanitarian intelligentsia under social pressure tried to turn the spectators to the Christian values. However, this problem was not solved: in the theatre, a radically minded audience wanted to hear, and heard only the revolutionary appeals to the "destruction of the building, which were built by the robbers and oppressors of the people." "Signals to revolt" were caught in the Satin discourses about the person in the dialogues of the "Deti solntsa" about the sense of life, the individual and society, about the fate of all mankind. All these arguments were "completely motiveless" by the understanding of the revolutionary spectators because they were done by those who did not accept the revolution. The Russian Theatre of that time both the capital and provincial ones, did not restrain those passions, but on the contrary, it could not "resist" the troubled mood of the masses.

A theatrical situation at the beginning of the XX century originally declared about the crisis of the Christian consciousness of the Russian society and the inability of the community "Vekhi" persuasion to stop the radicalization of the educated classes based on Christian moralizing.

\subsection{Formation of the Tatar Theatre}

February 13, 1905 the journal "Theatre and Art" published a declaration of the meeting of the group of playwrights and representatives of theatres which took place in St. Petersburg under the title "The needs of the Russian theatre /Notes of stage actors/", which highlighted the difficult conditions of the National Theatre. The authors of the" Memoirs " wrote that "many of the nations of the Russian state are very often deprived of the opportunity to hear their own language from the stage and see the images of their native way of life" (Brodovskaya 2013).

The revolution of 1905-1907 stirred progressive Tatar intellectuals who were actively involved in the revolutionary liberation movement that was spread throughout the country. The revolution brought the possibility of newspapers and magazines publication in their native language, which marked a new stage in the development of the culture. The performing arts also got new incentives for their development. There were clubs of active theatre lovers in Kazan.

In May 1906, the amateurs in the building of the countermen Union staged the dramas "Zhalkoye ditya" and "Beda ot lubvy." Before the start of the play the poet S. Ramiev made a speech and noted the great cultural value of the National Theatre establishment for the Tatar people. One participant of the play noted that the spectators greeted the performance with great enthusiasm, especially women were happy for the freedom and equality in the society of men. From the hall there rushed the appeals "Long live the youth!", "Long live the Tatar national theatre." The stage was full of fresh flowers.

In December 22, 1906, the play was staged for the second time in the building of "New Club». The posters of this performance appeared, it drew the attention of the Kazan citizens, the press and so it became the first Tatar performance. Mullanur and Nabi Vakhitovs, G. Kulahmetov, his sisters Shamsinur and Sufiya, a poet Sagit Ramiev, Amina Teregulova, Akram Kaybishev took an active participation in its organization (Gubaidullin, 1964).

It is important to note that the way of a national theatre formation was not an easy one and it happened in the struggle against the reactionary circles. Therefore, at the beginning of 1906 in Kazan the first Tatar amateur 
circles were organized. The mullahs sent a petition to the governor and the chief of the police to prohibit staging the plays as immoral, contradictory to Shariat, the plays which could lead to the destructive start in a patriarchal Muslim family." The mullahs of all mosques in their sermons cursed "the unrighteous", the organizers of shameful presentations and entertainments. The mullahs set on the reactionaries on the organizers of the circles. In Kazan, in case of the Black Hundreds attack the participants of the plays were accompanied everywhere by a group of armed youth. The same groups guarded the entrances to the theatres during performances. In spite of it, people wanted to see the plays, cursed by the clergy (Haychenko, 1975). In the same way the reactionary forces tried to prevent the play from its staging on the 22 of December in 1906 (Gubaidullin, 1964).

Tatar Theatre, which appeared in the years of revolution, developed in close cooperation with the Russian culture. Since its foundation in its repertoire together with the translated plays, we find the works by Gogol "Znenitba" and "Revisor". But its originators realized that the new theatre needed its own democratic repertoire. G.Kamal and G. Kulahmetov worked on a new repertoire.

G. Kamal wrote the plays "Rasputstvo", "Antichrist", which expose the feudal way of Tatar Society (Brodovskaya 2013). In 1907, he wrote the drama "Neschastniy yunosha", where he included the song translated into the Tatar language "Solntse vshodit i zakhodit" from the play by Gorky "na dnye" (Gainullin, 1944). The G. Kamal's play was shown in all cities of Russia, where there were Tatar spectators. The plot of an "unfortunate younker" had much in common with the works of Gorky, they showed tramps, sank to the "bottom of life" and people mutilated by the bourgeois society under capitalism. Kamal was close to the ideas of Gorky humanism, and he tried to bring his works to the Tatar people.

Gafur Kulahmetov also experienced the influence of Gorky and in 1907, he wrote the drama "Young life". On the cover of the play, he wrote: "This play is written in imitation of the famous Russian writer Maxim Gorky" (Gainullin, 1944). The play was written under the influence of the events of 1905, in his work G. Kulahmetov for the first time in Tatar literature turned to the theme of the working class. The play was written, of course, not as imitation, but under the influence of Gorky, in particular, in the second act the author showed the Russians and Tatars, subjected to the same oppression and violence by their class enemies, with whom they were fighting.

One of the interesting initiatives of the Tatar theatre in the revolutionary period was the "female performance", where all the organizers involved and even the orchestra - were exclusively women. They staged "Life with three wives."

On the April 2, 1907, the first literary and vocal meeting in the Tatar language was held in Kazan. On the meeting the "young forces" of Tatars acted with their works before a wide Tatar audience, in which they caroled not "love" and "eyes" but true life ... a life full of suffering and struggle." The poet Yafarov the youngest speaker of vocal works particularly impressed everyone with "Pesn molodogo tatarina" (Brodovskaya 2013).

Several charity performances were given in favor of Muslim students at Kazan University and Veterinary Institute; they showed "Zhenitba" by Gogol (Brodovskaya 2013).

Thus reconstructing the cultural life of Russia in the critical period of the country development, we see that much of the Volga region artistic and creative intelligentsia demonstrated, although inconsistently, with fluctuations, the desire to be engaged in a nationwide assault on tsarism. And the basis of this opposition to the regime were, first of all, "Asian" methods of government policy in the spiritual realm, which increasingly came into conflict with the pro-European system of values characteristic to the creative intelligentsia at the beginning of the century. The analysis of the sources and literature showed that in multi-ethnic region, the democratic opposition and conservative trends in culture, including the performing arts were clearly demonstrated. There were not ethnic or sectarian conflicts among the creative intelligentsia; they were united by general aims of the struggle against the autocracy.

A complex interdisciplinary nature of the problem identified peculiarities of its historiography. On the one hand, these are numerous works on historical memory On the other hand, these are works on the history of the Volga theatres at the beginning of the XX century. The founder of the theory of historical memory is considered to be the French sociologist Maurice Halbwachs (1980), who considered that history and historical memory is in many ways are opposite, "the history usually starts when a tradition ends and social memory breaks down."

The interest to the topic of historical memory increased after the Second World War. Historical memory was 
analyzed in the context of the responsibility of the Hitler regime for the war and war crimes. Another reason that influenced the growing interest to the historical memory was the emergence of philosophical postmodernism. Michel Foucault rejected the traditional view that science was the driving force for progress. Foucault applied the concept of "kontrpamyat" to the history, considering that historians do not seek for objective knowledge. But they serve the power "developing" the history within the contemporary discourses (Foucault, 1996).

A British historian - Marxist E. Hobsbawm in his book "the Invented Tradition» offered his own interpretation of historical memory. He wrote that some traditions, "that seem ancient ... sometimes are invented." "The invention of tradition - is a process of formalization and ritualization, which is related to the past, even if it happens by the mandatory repetitions» (Hobsbawm, 2009). To techniques of this kind, Hobsbawm refers the establishment of new parties, teaching, using the new ... textbooks, sport competitions, search for new heroes and symbols. The invention of traditions, by the Hobsbawm's observation happens in the societies that maintain the illusion of democracy. In addition, as if summing up, the French writer Pierre Nora said, "history kills memory" (Nora, 2005).

Russian authors, in particular, L.P. Repina $(2005 ; 2013)$ do not agree with the opposition of history and historical memory, as history is the process of studying the past, including the selection and preservation information about it and it is one of the manifestations of historical memory.

For the formation of the historical memory three factors are very important: 1) forgetting the past; 2) different ways of interpreting the same facts and events, and 3) discovery of the phenomena in the past, the interest to which is caused by actual problems of the current life (Repin and oth., 2004). People tend to forget some events and exaggerate the importance of the others. The reasons for which society "remembers" some events and "forgets" the others, let us understand how a society sees itself in history. This oblivion of historical facts may occur both naturally and because of deliberate manipulation of public consciousness of politics and ideology.

At the same time oblivion - is an essential element of the historical memory. Although, on the one hand, it distorts the image of the past, but on the other hand, without such a cut-off of the "extra information», a coherent, logical pattern of events cannot be restored and history will become a chaotic jumble of facts (Repin et al., 2004).

The idea that memory belongs to the individual, was formulated in the XVIII century and at the beginning of the XX century there appeared socio-psychological structures having a collective dimension, and there was a need to reemphasis of researchers attention from the individual study of memory to transpersonal.

At the end of the XX century, the problems of memory became in the center of attention of public consciousness and became the subject of the cultural sciences study. Particularly at that time, there were new approaches directed to the researches not only of the past reality, but the images of the past in the public consciousness. Memory of the past was regarded as a category of culture taking into account the principle of distinction and cultural diversity, as in different cultures the level of the demand for the past and the way of its representation varies, and a memorial function is realized in the cultural practices of various types.

According to O.G. Expe definition, historical science appears as one of the specific forms of cultural memory, or as a "science-based cultural memory of our time" (Repina, 2013).

In this article, it is impossible to list all the authors of publications on historical memory. Patrick Hutton one of the fundamental modern researchers of the problems gives a serious analysis of various concepts of historical memory (1993). Russian researchers I.M. Savelyev (2006; 2010), A.V. Poletaev (2006; 2010), L.P. Repina (2005; 2013) made the largest contribution to the study of the problem.

Now the question of the correlation of memory, knowledge of the past and history as a science remains unsolved. Although even the most convinced supporters of scientific historicism acknowledge that history and memory is not always possible to separate completely from each other.

A. Altshuller (1956), M. Gainullin (1944), H. Gubaidulin (1964), V. Musharova (2010), M. Rogachev (1956), Haychenko G. (1975) devoted their works to the study of the history of Volga region theatre. Based on a wide range of materials and documents of the central and local archives, the authors traced the dynamics of social and political behavior of the creative intelligentsia at all stages of the first Russian revolution development. The problem of formation and preservation of the historical memory of the first Russian revolution and the role of the Volga theatre personalities in this revolution, who took the side of the Social Democrats, were not considered in the previous studies. 


\section{Conclusion}

Historical memory has great potential power, the ability to save in the people minds the events of the past, which are converted to the values, defining the deeds and the actions of people. The impact of stereotypes of historical memory on the consciousness and behavior of people can consolidate the society, but can also have a negative impact. The social institutions and agencies functioning in the society determine formation of the historical memory: the educational system, cultural institutions (theatres, libraries, cinemas, and museums), literature and art, religion, educative institutions and organizations, the media.

Therefore, the problems of preservation and development of historical memory needs the state attention. It reflects in the teaching of history in educational institutions of different levels, in the nature of the information supplied through the mass media. We need the thought-out policy in the sphere of preservation and development of historical memory. Study and generalization of experience at this stage is of particular importance for developing such a policy. Of course, the problem of preservation and development of historical memory requires an interdisciplinary study.

\section{Recommendations}

The article submissions can be used in the teaching process, in creation generalizing works on the history and culture of Russia, in the up-bringing work with the students in decision-making in the social and cultural sphere.

\section{Acknowledgments}

The work is performed according to the Russian Government Program of Competitive Growth of Kazan Federal University.

\section{References}

Al'tshuller, A. Y. (1956). Provintsial'nyy teatr v period pervoy russkoy revolyutsii. Pervaya russkaya revolyutsiya i teatr. Moskva, 218-265.

Berdyayev, N. A. (1990). Smysl istorii. Moskva, 177.

Brodovskaya, L. N. (2008). Problemy kul'tury i iskusstva v "levoy" publitsistike Povolzh'ya vremen pervoy russkoy revolyutsii. Obshchestvenno politicheskaya mysl' i dukhovnaya kul'tura narodov Povolzh'ya i Priural'ya (XIX-XX vv.). Problemy izucheniya. Kazan, 358-361

Brodovskaya, L. N. (2009). "Vekovaya bol"' krest'yanstva na podmostkakh russkogo teatra vremen revolyutsii 1905 goda. Izvestiya obshchestva istorii, arkheologii i etnografii pri Kazanskom gosudarstvennom universitete. Kazan, 174-178.

Brodovskaya, L. N. (2012). Podkhody k razvitiyu mezhnatsional'nykh otnosheniy v prepodavanii istoricheskikh distsiplin. Traditsii i novatsii v sfere etnokonfessional'nykh vzaimodeystviy. Kazan, 215-219

Brodovskaya, L. N. (2013). Vzaimovliyaniye kul'tur v sfere teatral'nogo iskusstva v mnogonatsional'nom Povolzhskom regione. Sotsiokul'turnyy potentsial mezhkonfessional'nogo dialoga. Kazan, 246-252

Brodovskaya, L. N., Buravleva, V. V., \& Gafarov, A. A. (2012). Problemy «inorodcheskogo» obrazovaniya musul'man v Rossiyskoy imperii (konets XIX-nachalo XX vv.). Obrazovaniye i samorazvitiye. Nauchnyy zhurnal, 4(32), 171-176.

Buravleva, V. V., \& Gafarov, A. A. (2012).Sotsiokul'turnyye sdvigi v zhizni rossiyskikh musul'man v kontekste obshcheislamskoy modernizatsii (XIX v.). Vestnik Kazanskogo gosudarstvennogo universiteta kul'tury i iskusstva, 4, 141-146.

Fuko, M. (1996). Arkheologiya znaniya. Kiyev, 208.

Gaynullin, M. K. (1944). Gor'kiy i tatarskaya literatura. Kazan, 158.

Gubaydullin, K. H. (1964). Tatarskiy teatr dooktyabr'skogo perioda (Kandidatskaya dissertatsiya). Kazan,190.

Halbwachs, M. (1980). The collective Memory. New York, Harper and Row: Colophon Books, 207-227.

Halbwachs, M. (1980). The collective Memory. New York, Harper and Row: Colophon Books, 207-227.

Hobsbawm, E. (2009). Introduction: Inventing Traditions. The Invention of Tradition. Cambridge, 1-7. http://dx.doi.org/10.1017/cbo9781107295636.001

Hutton, P. H. (1993). History as an Art of Memory. Hanover, New Hampshire: University Press of New England, 229.

Khaychenko, G. A. (1975). Narodnyy teatr. Russkaya khudozhestvennaya kul'tura kontsa XIX - nachala XX veka 
(1895-1907). Kn. 1. Moskva, 356.

Musharova, V. M. (2010). Istoriya kul'tury Tatarstana. Kazan, 288.

Nora, P. (2005). Vsemirnoye torzhestvo pamyati. Neprikosnovennyy zapas, 2-3, 206-207.

Repina, L. P. (2005). Kontseptsii sotsial'noy i kul'turnoy pamyati v sovremennoy istoriografii. Fenomen proshlogo. Moskva, 122-169.

Repina, L. P. (2013). Pamyat' o proshlom v prostranstve kul'tury. Dialog so vremenem: Al'manakh intellektual'noy istorii. 43. Moskva, 196-197.

Repina, L. P. Zvereva, V. V., \& Paramonova, M. Y. (2004). Istoriya istoricheskogo znaniya. Moskva, 288.

Rogachevskiy, M. (1956). Moskovskiy khudozhestvennyy teatr v epokhu pervoy russkoy revolyutsii. Pervaya russkaya revolyutsiya i teatr. Moskva, 74-126.

Savel'yeva, I. M., \& Poletayev, A. V. (2006). Znaniye o proshlom: teoriya i istoriya. T. 1. Konstruirovaniye. Sankt-Peterburg: G1.5.

Savel'yeva, I. M., \& Poletayev, A. V. (2010). Istoriya v sisteme sotsial'nogo znaniya. Sposoby postizheniya proshlogo. Metodologiya i teoriya istoricheskoy nauki. Moskva, 50-84

Smykov, Y. I., \& Shishkin, V. I. (2002). Posledniye gody pod dvuglavym orlom: 1901-1917gg. Ocherki istorii Kazanskogo universiteta. Kazan, 123-148.

Stanislavskiy, K. S. (1953). Stat'i, rechi, besedy, pis'ma. Moskva, 782.

\section{Copyrights}

Copyright for this article is retained by the author(s), with first publication rights granted to the journal.

This is an open-access article distributed under the terms and conditions of the Creative Commons Attribution license (http://creativecommons.org/licenses/by/3.0/). 